\title{
Adela Mora Cañada, in memoriam
}

\author{
DOI: http://dx.doi.org/10.20318/cian.2016.3148
}

El pasado mes de febrero, de manera repentina y dejándonos a todos muy tristes, falleció la profesora Adela Mora Cañada. Adela fue la primera y única directora de CIAN-Revista de Historia de las Universidades hasta que hace cuatro años quien esto escribe asumió su testigo. Con alegría, inmenso cariño y mucha perseverancia Adela puso en marcha este proyecto editorial en el que, siempre acompañada de Manuel Martínez Neira y Manuel Bermejo, no dejó nunca de buscar y alentar las contribuciones que mejor pudieran encajar en la revista

Profunda conocedora de la historia universitaria española y, por supuesto, de la latinoamericana son citados y básicos en cualquier bibliografía especializada sus trabajos sobre las Universidades de México en 1700 o sobre la Universidad Real de San Felipe en Santiago de Chile. Y lo son también sus textos sobre enfiteusis y sobre procedimientos mercantiles en la Valencia del siglo XVIII así como sus traducciones de nuevos trabajos de iushistoriadores italianos a los que estaba dedicando sus esfuerzos últimos.

Adela Mora era brillante investigadora, tenaz e innovadora docente y una excelente gestora de nuevos proyectos, como lo fue el de esta revista hace casi veinte años. Pero sobre todo era una persona amable, cercana y siempre dispuesta a escuchar, dialogar y trabajar en equipo. Cuesta pensar que no podremos contar con ella para consultarle una duda, contarle una nueva idea o ponerle al corriente de nuestras novedades, con las que siempre tanto se alegraba. El trabajo que desde esta revista desarrollan la dirección y el consejo de redacción es deudor de su esfuerzo e inspiración y a ella seguiremos dedicando nuestros desvelos aquí. Hasta siempre, Adela. 